\title{
Production of Synbiotic Yogurt-Like Using Indigenous Lactic Acid Bacteria as Functional Food
}

\author{
M. Astawan ${ }^{\mathrm{a}, *}$, T. Wresdiyati ${ }^{\mathrm{b}, \sharp}$, Suliantaria $^{\mathrm{a}}$, I. I. Arief ${ }^{\mathrm{c}, \#}$, \& R. Septiawan ${ }^{\mathrm{a}}$ \\ apepartment of Food Science and Technology, Faculty of Agricultural Engineering and Technology, \\ Bogor Agricultural University \\ Jln. Kamper, Darmaga IPB Campus, Bogor 16680, Indonesia \\ bDepartment of Anatomy, Physiology, and Pharmacology, Faculty of Veterinary Medicine, \\ Bogor Agricultural University \\ 'Department of Animal Production and Technology, Faculty of Animal Science, Bogor Agricultural University \\ \#Jln. Agatis, Darmaga IPB Campus, Bogor 16680, Indonesia \\ (Received 02-01-2011; accepted 15-02-2012)
}

\begin{abstract}
ABSTRAK
Yogurt adalah produk susu fermentasi yang dibuat dengan menggunakan bakteri Lactobacillus bulgaricus dan Streptococcus thermophilus sebagai kultur starter. Bakteri asam laktat indigenus Lactobacillus plantarum 2C12 atau Lactobacillus acidophilus 2B4 digunakan sebagai probiotik pada pembuatan minuman fungsional susu fermentasi sinbiotik yang ditambahkan $5 \%$ fruktooligosakarida (FOS) sebagai sumber prebiotik. Tujuan penelitian ini adalah untuk menentukan formula terbaik dari susu fermentasi sinbiotik berbasis yoghurt diantara empat formula: F1 ( $L$. bulgaricus + S. thermophilus), F2 (L. bulgaricus + S. thermophilus + L. plantarum 2C12), F3 (L. bulgaricus + S. thermophilus + L. acidophilus $2 \mathrm{~B} 4)$, and $\mathrm{F} 4$ (L. bulgaricus + S. thermophilus + L. plantarum $2 \mathrm{C} 12+$ L. acidophilus 2B4). Hasil penelitian menunjukkan bahwa susu fermentasi sinbiotik berbasis yoghurt F3 mempunyai aktivitas antibakteri terbaik terhadap Escherichia coli enteropatogenik (EPEC). Penambahan tepung jagung 1,75\% sebagai stabilizer mampu meningkatkan konsistensi yoghurt dan meminimalisasi terbentuknya whey. Hasil evaluasi sensori mengindikasikan bahwa penambahan flavor stroberi $1 \%$ lebih baik daripada vanila $0,1 \%$. Susu fermentasi berbasis yoghurt $\mathrm{F} 3$ masih dapat dikonsumsi dengan baik untuk penyimpanan selama 15 hari pada suhu refrigerator $\left(10^{\circ} \mathrm{C}\right)$.
\end{abstract}

Kata kunci: susu fermentasi yoghurt, sinbiotik, bakteri asam laktat indigenus, pangan fungsional

\section{ABSTRACT}

Yoghurt is a product of fermented milk using Lactobacillus bulgaricus and Streptococcus thermophilus as culture starter. Indigenous probiotic lactic acid bacteria, Lactobacillus plantarum $2 \mathrm{C} 12$ or Lactobacillus acidophilus 2B4, were applied in the making of functional synbiotic yoghurt-like with $5 \%$ of fructo-oligosaccharide (FOS) as a prebiotic source. The aim of this study was to determine the best formula of functional synbiotic yoghurt-like among four formulas: F1 (L. bulgaricus + S. thermophilus), F2 (L. bulgaricus + S. thermophilus + L. plantarum 2C12), F3 (L. bulgaricus + S. thermophilus + L. acidophilus $2 \mathrm{~B} 4)$, and $\mathrm{F} 4($. bulgaricus $+S$. thermophilus + L. plantarum $2 \mathrm{C} 12+$ L. acidophilus 2B4) to be choosen and followed detection of it's flavor to improve the product quality and consumer acceptance. The results showed that the F3 synbiotic yogurt made from mixed culture L. bulgaricus, S. thermophilus, and L. acidophilus 2B4 had the highest antibacterial effect against Enteropathogenic Escherichia coli (EPEC). Addition of $1.75 \%$ natural corn starch as a stabilizer produced optimum improvement in yoghurt consistency and minimize whey separation. Result of sensory evaluation indicated that the yoghurt with addition of $1 \%$ strawberry flavor and $0.1 \%$ vanilla flavor were ranked at first and second. Yoghurts were still good to be consumed after $15 \mathrm{~d}$ storage period at the refrigeration temperature $\left(10^{\circ} \mathrm{C}\right)$.

Key words: yoghurt-like, synbiotic, indigenous lactic acid bacteria, functional food

*Corresponding author:

E-mail: mastawan@yahoo.com 


\section{INTRODUCTION}

Yoghurt is a fermented drinks which is made from fresh milk or skimmed milk using indigenous lactic acid bacteria as a starter. According to Indonesian National Standard (2009), yoghurt is a fermentation product of fresh milk and or reconstituted milk by using bacteria, such as Lactobacillus bulgaricus and Streptococcus thermophilus with or without any additional food materials and permitted food additives. Yoghurt as a viscous liquid drink with sour taste (from lactic acid accumulation) and spesific flavor (from acetaldehyde component, a small number diacetyl, aceton, acetoine, etc) is a result from activity of lactic acid bacteria starter within the fermented milk.

Nowadays, yoghurt is an interested drink by many people in Indonesia. Yoghurt has been known as a product which contains so many essential components for consumer health. Yoghurt bacteria, Lactobacillus bulgaricus and Streptococcus thermophilus are not able to survive inside the digestive tract so that do not work properly in the human digestive tract (Lourens-Hattingh \& Viljoen, 2001). Therefore, another probiotic bacteria is necessarily needed to be added into yoghurt. The probiotic bacteria shoud be able to survive, reproduce, compete in adhesion and fermented substrates, and able to produce antimicrobial substances in the human digestive tract, so that can maintain stability of intestinal microflora (Lee \& Salminen, 2009).

To increase the functional value of yoghurt, the addition of probiotic microbial should be derived from local area or categorized as an indigenous material. Some isolated lactic acid bacteria from beef in some traditional market around Bogor had been known to have probiotic criteria (Arief et al., 2010). Local probiotic microbes have some excellences, like able to adapt within local environment condition, so that do not need any more modifications and manipulations from its original character. Those lactic acid bacteria are hoped not only can inhibit the growth of pathogenic microbes but also capable to maintain the stability of intestinal microflora of Indonesian people better.

In this research, indigenous lactic acid bacteria (Lactobacillus plantarum 2C12 and Lactobacillus acidophilus 2B4) were used as probiotics. These bacteria had been proved to prevent diarrhea caused by EPEC according to Arief et al. (2010) and repaired the hematology condition of diarrheal suspected rats (Astawan et al., 2011a). Besides a probiotic, it was also added fructooligosaccharide (FOS) as a prebiotic source, to produce synbiotic yoghurt (Paseephol \& Sherkat, 2009). Synbiotic is the mixture of probiotic and prebiotic which is very useful for digestive tract of the host (Andersson et al., 2001).

The objective of this research was to apply two indigenous probiotic lactic acid bacteria (L. plantarum 2C12 and L. acidophilus 2B4) according to the research of Arief et al. (2010), Astawan et al. (2011b), Astawan et al. (2011c) in producing a synbiotic yoghurt that is able to prevent diarrhea caused by EPEC infection on the rats model.

\section{MATERIALS AND METHODS}

\section{Material}

The main materials used in this reseacrh were skimmed milk powder, sugar, FOS, lactic acid bacteria isolates (L. bulgaricus and S. thermophilus), indigenous probiotic isolates (L. plantarum $2 \mathrm{C} 12$ and L. acidophilus 2B4), EPEC isolate, de-Man Rogosa Sharp (MRS) broth, deMan Rogosa Sharp (MRS) agar, Eosin Methylen Blue Agar (EMBA), Potato Dextrose Agar (PDA), and carboximethyl cellulose (CMC).

\section{Preparation of Lactic Acid Bacteria Starter}

Firstly, pure culture lactic acid bacteria was refreshed on MRSB media and incubated at $37^{\circ} \mathrm{C}$ for $24 \mathrm{~h}$. About $2 \%$ of refreshed culture was inoculated into sterile $10 \%$ skimmed milk solution and incubated at $37^{\circ} \mathrm{C}$ for $24 \mathrm{~h}$. The result of this incubated culture was called parent culture.

About $2 \%$ of parent culture was inoculated into $10 \%$ solution of skimmed milk and $2 \%$ of pure glucose, then incubated at $37^{\circ} \mathrm{C}$ for $24 \mathrm{~h}$. The result was called working culture. The working culture was poured onto MRSA media to calculate its population. Culture that fulfills the requirements was used as starter culture. Yoghurt starter is a culture with total number of population more than or equal to $10^{8} \mathrm{cfu} / \mathrm{ml}$.

\section{Production of Synbiotic Yoghurt}

The production process of synbiotic yoghurt was started by dissolving 5\% sugar, 5\% FOS, and skimmed milk to produce yoghurt with $22 \%$ of total solid. Then, the solution was pasteurized at $90{ }^{\circ} \mathrm{C}$ for $30 \mathrm{~min}$., then cooled until reach $37{ }^{\circ} \mathrm{C}$, and added $2 \%$ of starter. Fermentation process was held in the incubator at $37^{\circ} \mathrm{C}$ for $12 \mathrm{~h}$ (Lourens-Hattingh \& Viljoen, 2001).

There were four different yoghurt formulas based on bacteria used in the process, namely: formula 1 ( $L$. bulgaricus $+S$. thermophilus), formula 2 (L. bulgaricus $+S$. thermophilus + L. plantarum 2C12), formula 3 (L. bulgaricus + S. thermophilus + L. acidophilus 2B4), and formula 4 (L. bulgaricus $+S$. thermophilus + L. plantarum $2 \mathrm{C} 12+L$. acidophilus 2B4). Each formula was added with 5\% FOS as a prebiotic.

\section{Analysis of Antibacterial Activity}

Analysis of antibacterial activity from synbiotic yoghurt was conducted by investigating the yoghurt inhibition effect on pathogenic bacteria of Enteropathogenic Escherichia coli (EPEC). This analysis was done with contact methode by counting the reduction number of EPEC bacteria after contacting with yoghurt.

The number of EPEC bacteria was counted by culturing EPEC on EMBA (Eosin Methylene Blue Agar) media, and then incubated at $37^{\circ} \mathrm{C}$ for $24 \mathrm{~h}$. Meanwhile, to evaluate the effect of the yoghurt formula, EPEC bacteria (1\%) was inoculated to each yoghurt formula and then incubated for 2,4 , and $6 \mathrm{~h}$ at $37^{\circ} \mathrm{C}$. The determination of 
the mixture time was based on the EPEC growing curve, where 2, 4, and $6 \mathrm{~h}$ are the time of E. coli to be on log phase (Quigley, 2008).

The final number of EPEC bacteria was counted by culturing on EMBA media, then incubated at $37{ }^{\circ} \mathrm{C}$ for $24 \mathrm{~h}$. The antibacterial effect of each yoghurt formula was shown by the reduction number of EPEC. Then, yoghurt formula with the highest reduction of EPEC was choosen as the best formula that would be optimized to be a marketable product.

\section{Addition of Stabilizer}

Addition of stabilizer was done into six sample yoghurt formulas (three formulas with CMC and three formulas with corn starch). One formula without the addition of stabilizer was used as a control. The variations of CMC concentration were $0.1 \%, 0.15 \%$, and $0.2 \%$, meanwhile for corn starch were $1.5 \%, 1.75 \%$, and $2.0 \%$, Determination of the best stabilizer material was based on the sensory parameter consisting of color, taste, flavor, texture, the amount of whey, physical and chemical parameters that consist of $\mathrm{pH}$, viscosity, and titratable acidity.

\section{Addition of Flavor}

The types of flavor added were vanilla $(0.1 \%$ and $0.2 \%)$ and strawberry extract ( $1 \%$ and $2 \%)$. The best flavor was determined by organoleptic analysis (rating test and hedonic test), using 30 of semi-trained panelists.

\section{Shelf Life Analysis}

Shelf life analysis was done on the best synbiotic yoghurt based on the result of sensory analysis. The shelf life analysis was conducted at refrigeration temperature $\left(10{ }^{\circ} \mathrm{C}\right)$ for $15 \mathrm{~d}$. In order to know the changes occured during the storage time, some parameters were analyzed every three days. The observed parameters during storage consisted of sensory parameters (hedonic and ranking test), $\mathrm{pH}$ value, titratable acidity, viscosity, lactic acid bacteria viability, and yeast-mold contamination. Sensory analysis was conducted by 30 of semi-trained panelists.

\section{Analysis of Yoghurt Characteristic}

Analysis of yoghurt characteristic included physical analysis (degree of acidity with $\mathrm{pH}$-meter and viscosity with Brookfield viscometer), chemical analysis (titratable acidity, water, ash, lipid, protein, and carbohydrate contents), and microbiological analysis (total of Coliform and Salmonella) (AOAC, 2005).

\section{RESULTS AND DISCUSSION}

\section{Selection of the Best Synbiotic Yoghurt Formula}

There was no significant difference on antimicrobial activity of yoghurt toward EPEC (Table 1). The average of EPEC death log number on F3 yoghurt was 3.4319.
The result indicated that F3 yoghurt had the best physical appearances, consistency, and also produced the fewest whey.

The acidity level (pH) of F1, F2, F3, and F4 yoghurts was 4.61, 4.37, 4.51, and 4.42, respectively. F3 yoghurt had $\mathrm{pH}$ value about 4.51 , close to the average $\mathrm{pH}$ value of commercial yoghurt, about 4.5 (SNI, 2009). Paseephol \& Sherkat (2009) found the $\mathrm{pH}$ of 4.1-4.5 in inulin prebiotic added yoghurt.

F3 yoghurt contained L. acidophilus 2B4. In general, L. acidophilus has the potency as probiotic (Tharmaraj \& Shah, 2004), since the bacteria has a high tolerance to low $\mathrm{pH}$ value, resistant to bile salt, and has antimicrobial activity on pathogenic bacteria. L. acidophilus 2B4 has also shown ability to be function as probiotic preventing diarrhea on EPEC infected rats (Arief et al., 2010; Astawan et al., 2011b).

\section{Addition of Stabilizer}

Stabilizers addition could improve the yoghurt consistency, viscosity, and eliminate the whey production (Chandan et al., 2006). Addition of corn starch showed better contribution to the yoghurt consistency than CMC (Tabel 2). Generally, addition of corn starch stabilizer produced a lesser amount of whey than CMC. The addition of CMC also produced a non interesting yellow color of whey.

The addition of corn starch produced yoghurt with more sour and higher viscosity (Table 3). This was associated with the lower $\mathrm{pH}$ value and higher viscosity of the product. Generally, the titratable acidity had fulfilled the requirements of Indonesian National Standard quality for yoghurt, about $0.5 \%-2.0 \% \mathrm{w} / \mathrm{w}$ (SNI, 2009).

The corn starch stabilizer produced a better yoghurt. Yoghurt with addition of 1.7 and $2.0 \%$ corn starch had a softer texture and fewer whey than that with $1.5 \%$ corn starch. However, from the stand point of lower $\mathrm{pH}$ value, higher total lactic acid number, and economic aspect, the concentration of $1.75 \%$ corn starch was better than that of $2.0 \%$. Therefore corn starch $1.75 \%$ was chosen as stabilizer on this research.

Table 1. Antibacterial activity of synbiotic yoghurt on Enteropathogenic Escherichia coli (EPEC) based on contact methode for 2,4 , and $6 \mathrm{~h}$

\begin{tabular}{ccccc}
\hline \multirow{2}{*}{ Formula } & \multicolumn{4}{c}{ Average death number of EPEC $(\log \mathrm{cfu} / \mathrm{ml})$} \\
\cline { 2 - 5 } & $\begin{array}{c}2 \mathrm{~h} \\
\text { contact }\end{array}$ & $\begin{array}{c}4 \mathrm{~h} \\
\text { contact }\end{array}$ & $\begin{array}{c}6 \mathrm{~h} \\
\text { contact }\end{array}$ & Average \\
\hline F1 & $2.78 \pm 0.54^{\mathrm{a}}$ & $3.02 \pm 0.25^{\mathrm{a}}$ & $3.98 \pm 0.26^{\mathrm{a}}$ & $3.2623 \pm 0.6358^{\mathrm{a}}$ \\
F2 & $2.73 \pm 0.23^{\mathrm{a}}$ & $3.15 \pm 0.50^{\mathrm{a}}$ & $4.07 \pm 0.48^{\mathrm{a}}$ & $3.3197 \pm 0.6863^{\mathrm{a}}$ \\
F3 & $2.69 \pm 0.30^{\mathrm{a}}$ & $3.54 \pm 0.38^{\mathrm{a}}$ & $4.31 \pm 0.88^{\mathrm{a}}$ & $3.4319 \pm 0.8218^{\mathrm{a}}$ \\
F4 & $2.51 \pm 0.72^{\mathrm{a}}$ & $3.61 \pm 0.23^{\mathrm{a}}$ & $4.19 \pm 0.43^{\mathrm{a}}$ & $3.3593 \pm 0.8430^{\mathrm{a}}$ \\
\hline
\end{tabular}

Note: Means in the same column with different superscript differ significantly $(\mathrm{P}<0.05)$. F1: Formula 1 (L. bulgaricus + S. thermophilus), F2: Formula 2 (L. bulgaricus + S. thermophilus + L. plantarum 2C12), F3: Formula 3 (L. bulgaricus + S. thermophilus + L. acidophilus 2B4), F4: Formula 4 (L. bulgaricus $+S$. thermophilus + L. plantarum $2 \mathrm{C} 12+L$. acidophilus 2B4). 
Table 2. Sensory characteristic of F3 yoghurt based on the addition of stabilizers

\begin{tabular}{|c|c|c|c|c|c|}
\hline \multirow[t]{2}{*}{ Type of stabilizer } & \multicolumn{4}{|c|}{ Sensory characteristic } & \multirow{2}{*}{$\begin{array}{l}\text { Whey } \\
\text { Color }\end{array}$} \\
\hline & Taste & Aroma & Texture & Whey & \\
\hline CMC $0.1 \%$ & Sour & Normal & Soft, solid & Many & Yellow \\
\hline CMC $0.15 \%$ & Sour & Normal & Soft, solid & Little & Yellow \\
\hline $\mathrm{CMC} 0.2 \%$ & Sour & Normal & $\begin{array}{l}\text { A bit rough, } \\
\text { rather dilute }\end{array}$ & So many & Yellow \\
\hline Corn starch $1.5 \%$ & Sour & Normal & Solid & Little & White \\
\hline Corn starch $1.75 \%$ & Sour & Normal & Soft, solid & So many & White \\
\hline Corn tarch $2.0 \%$ & Sour & Normal & Soft, solid & Very little & White \\
\hline Control & Sour & Normal & Soft, solid & Little & White \\
\hline
\end{tabular}

Note: F3: Formula 3 (L. bulgaricus + S. thermophilus + L. acidophilus 2B4); CMC: carboximethyl cellulose.

Table 3. Physical and chemical characteristics of F3 yogurt based on type of stabilizers

\begin{tabular}{lccc}
\hline Type of stabilizer & $\mathrm{pH}$ & $\begin{array}{c}\text { Viscosity } \\
(\mathrm{cP})\end{array}$ & $\begin{array}{c}\text { Titratable } \\
\text { acidity }(\% \mathrm{w} / \mathrm{w})\end{array}$ \\
\hline CMC 0.1\% & $4.92 \pm 0.01^{\mathrm{e}}$ & $3,300 \pm 141^{\mathrm{c}}$ & $1.65 \pm 0.01^{\mathrm{de}}$ \\
CMC 0.15\% & $4.90 \pm 0.01^{\mathrm{d}}$ & $3,300 \pm 141^{\mathrm{c}}$ & $1.59 \pm 0.00^{\mathrm{c}}$ \\
CMC 0.2\% & $4.90 \pm 0.00^{\mathrm{d}}$ & $1,200 \pm 0^{\mathrm{a}}$ & $1.56 \pm 0.00^{\mathrm{b}}$ \\
Corn starch 1.5\% & $4.39 \pm 0.01^{\mathrm{a}}$ & $8,900 \pm 141^{\mathrm{d}}$ & $1.70 \pm 0.00^{\mathrm{f}}$ \\
Corn starch 1.75\% & $4.40 \pm 0.01^{\mathrm{a}}$ & $12,300 \pm 141^{\mathrm{e}}$ & $1.65 \pm 0.00^{\mathrm{e}}$ \\
Corn starch 2.0\% & $4.46 \pm 0.00^{\mathrm{b}}$ & $13,000 \pm 282^{\mathrm{f}}$ & $1.64 \pm 0.00^{\mathrm{d}}$ \\
Control & $4.59 \pm 0.00^{\mathrm{c}}$ & $2,800 \pm 0^{\mathrm{b}}$ & $1.54 \pm 0.00^{\mathrm{a}}$ \\
\hline
\end{tabular}

Note: Means in the same column with different superscript differ significantly $(\mathrm{P}<0.05)$. F3: Formula 3 (L. bulgaricus + S. thermophilus $+L$. acidophilus 2B4); CMC: carboximethyl cellulose.

\section{Addition of Flavor}

The F3 yoghurt formula with $1.75 \%$ of corn starch was then added flavors to attain product variation and improve the consumer acceptance level. The most favourite yoghurt was F3 formula with the addition of $1 \%$ strawberry and $0.1 \%$ vanilla (Table 4 ). The formula indicated the higher hedonic scale of panelists for every parameter and also had the highest hedonic ranking number. Generally, it was shown that flavor addition on yoghurt could improve the consumer acceptability.

\section{Yoghurt Quality}

Yoghurt quality was observed by evaluating water, ash, fat, protein, and carbohydrate contents, metal contaminant, and microbiological contaminant. All analysis were done on plain yoghurt, strawberry yoghurt, and vanilla yoghurt.

All selected yoghurt formulas (Table 5 ) had fulfilled the Indonesian National Standard of yoghurt (SNI 29812009). All of the yoghurts were categorized as fat free, but high in protein content. All yoghurts were produced by using skim milk powder that high in protein but low in fat contents.

\section{Yoghurt Quality during Cooling Storage}

Shelf life analysis was made to investigate the changes on quality of yoghurt product during storage. Figure 1 indicated that the $\mathrm{pH}$ value of yoghurt tended to decrease, whereas the titratable acidity value increased. The reduction of yoghurt $\mathrm{pH}$ was caused by lactic acid produced during the storage. This was relevant with the elevation of the titratable acidity value of yoghurt that was counted as total lactic acid.

Table 4. Sensory attributes of F3 yoghurt based on type of flavor (rating hedonic test)

\begin{tabular}{|c|c|c|c|c|c|}
\hline \multirow{2}{*}{ Type of flavor } & \multicolumn{5}{|c|}{ Hedonic value $^{1}$} \\
\hline & Color & Aroma & Texture & Taste & Overall \\
\hline Plain & $5.40 \pm 1.25^{\mathrm{bc}}$ & $4.60 \pm 1.16^{\mathrm{a}}$ & $4.60 \pm 1.19^{\mathrm{b}}$ & $3.83 \pm 1.51^{\mathrm{a}}$ & $4.10 \pm 1.35^{\mathrm{a}}$ \\
\hline Vanilla $0.1 \%$ & $5.53 \pm 1.07^{\mathrm{bc}}$ & $5.17 \pm 1.26^{\mathrm{a}}$ & $4.77 \pm 1.50^{\mathrm{bc}}$ & $5.20 \pm 1.32^{c}$ & $5.03 \pm 1.13^{\mathrm{b}}$ \\
\hline Vanilla $0.2 \%$ & $4.77 \pm 1.50^{\mathrm{a}}$ & $4.63 \pm 1.10^{\mathrm{a}}$ & $3.83 \pm 1.62^{\mathrm{a}}$ & $4.23 \pm 1.65^{\mathrm{a}}$ & $4.27 \pm 1.51^{\mathrm{a}}$ \\
\hline Strawberry $1 \%$ & $5.60 \pm 1.19^{c}$ & $4.73 \pm 1.31^{\mathrm{a}}$ & $5.37 \pm 1.16^{c}$ & $5.07 \pm 1.34^{\text {bc }}$ & $5.17 \pm 1.23^{\mathrm{b}}$ \\
\hline Strawberry $2 \%$ & $4.97 \pm 1.50^{\mathrm{ab}}$ & $4.63 \pm 1.03^{\mathrm{a}}$ & $5.00 \pm 1.11^{\mathrm{bc}}$ & $4.40 \pm 1.48^{\mathrm{ab}}$ & $4.67 \pm 1.21^{\mathrm{ab}}$ \\
\hline
\end{tabular}

Note: Means in the same column with different superscript differ significantly $(\mathrm{P}<0.05)$. ${ }^{1}$ Based on seven point scale $(1=$ extremely desirable; $7=$ extremely undesirable). F3: Formula 3 (L. bulgaricus + S. thermophilus + L. acidophilus 2B4); CMC: carboximethyl cellulose. 
Table 5. F3 yoghurt quality characteritics

\begin{tabular}{|c|c|c|c|c|c|}
\hline Characteristics & Unit & Plain yoghurt & $\begin{array}{c}\text { Strawberry } \\
\text { yoghurt }\end{array}$ & Vanilla yoghurt & Yoghurt SNI \\
\hline Water & $\% \mathrm{w} / \mathrm{w}$ & 74.53 & 75.59 & 74.9 & - \\
\hline Ash & $\% \mathrm{w} / \mathrm{w}$ & 1.00 & 1.00 & 1.00 & $\max .1 .00$ \\
\hline Lipid & $\% \mathrm{w} / \mathrm{w}$ & 0.16 & 0.16 & 0.16 & max. 0.5 (fat free) \\
\hline Protein & $\% \mathrm{w} / \mathrm{w}$ & 6.14 & 5.79 & 5.88 & $\min .2 .7$ \\
\hline Carbohydrate & $\% \mathrm{w} / \mathrm{w}$ & 18.17 & 17.46 & 18.06 & - \\
\hline \multicolumn{6}{|l|}{ Metal contaminant } \\
\hline Plumbum $(\mathrm{Pb})$ & $\mathrm{mg} / \mathrm{kg}$ & - & $<0.030$ & $<0.030$ & max. 0.3 \\
\hline Copper $(\mathrm{Cu})$ & $\mathrm{mg} / \mathrm{kg}$ & - & 1.92 & 8.78 & $\max .20 .0$ \\
\hline Tin (Sn) & $\mathrm{mg} / \mathrm{kg}$ & - & $<0.010$ & $<0.010$ & $\max .40 .0$ \\
\hline Mercury (Hg) & $\mathrm{mg} / \mathrm{kg}$ & - & $<0.001$ & $<0.001$ & $\max .0 .03$ \\
\hline Arsenic (As) & $\mathrm{mg} / \mathrm{kg}$ & - & $<0.010$ & $<0.010$ & max. 0.1 \\
\hline \multicolumn{6}{|c|}{ Microbial contaminant } \\
\hline Colliform & $\mathrm{MPN} / \mathrm{g}$ & $<3$ & $<3$ & $<3$ & $\max .10$ \\
\hline Salmonella & - & negative & negative & negative & negative $/ 25 \mathrm{~g}$ \\
\hline
\end{tabular}

Note: Means in the same column with different superscript differ significantly $(\mathrm{P}<0.05)$. F3: Formula 3 (L. bulgaricus + S. thermophilus + L. acidophilus 2B4); CMC: carboximethyl cellulose.

This reduction of $\mathrm{pH}$ value enhanced the sour and unique flavor of yoghurt during storage (Paseephol \& Sherkat, 2009). During $15 \mathrm{~d}$ of storage, the total lactic acid of yoghurt met the SNI requirement of $0.5 \%-2.0 \%$. Yoghurt was still feasible to be consumed during the 15 d of storage.

Yoghurt viscosity changed during the storage (Figure 2). The longer the product was stored, the protein particle combined lazier each other to form heavy particles and then easily sedimented. The cooling and storage process after fermentation increased viscosity caused by protein hydration and compaction of yoghurt gel structure. The changes of milk acidity affected protein isoelectric point and changed the protein solubility. Whereas the reduction of viscosity was probably caused by formation of colloidal protein and its degradation during the storage. According to Chandan et al. (2006), the viscosity of commercial yoghurt is in the range 12,000-30,000 cP.

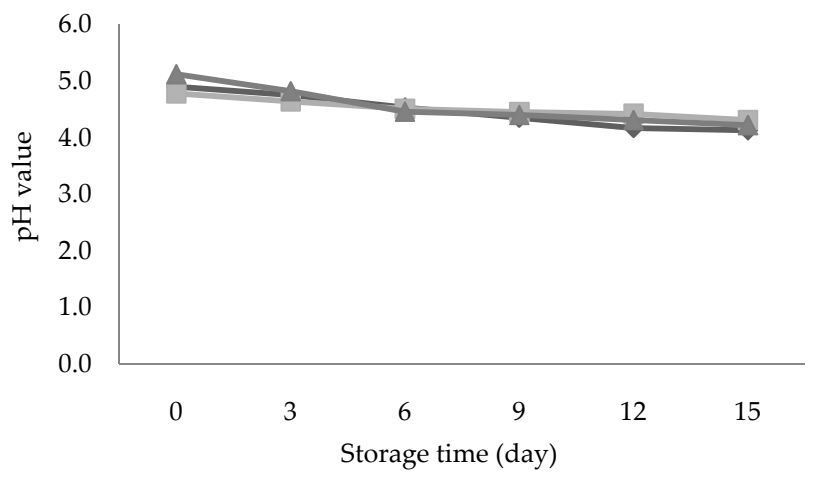

A
The viability of lactic acid bacteria in yoghurt decreased during the storage (Figure 3). The decrease of bacterial viability was related to the reduction of lactose as a main source of carbon for the bacteria. Nevertheless, the viability of lactic acid bacteria in yoghurt after storage for $15 \mathrm{~d}$ was still high and more than $10^{9} \mathrm{cfu} / \mathrm{ml}$. Total number of probiotic contributing to health status is still controversial, but some researchers states that the therapy dosage is between $10^{7}-10^{8} \mathrm{cfu} / \mathrm{ml}$ (Zubillaga et al., 2001), or $10^{8}$ probiotic cell alive per day (LourensHattingh \& Viljoen, 2001).

The analysis for total of mold and yeast on yoghurt during storage showed that there were no any mold and yeast detected. The result indicated that yoghurt was produced and packaged in good hygienic practices. This result also showed that the yoghurt was still good to be consumed up to $15 \mathrm{~d}$ in $10^{\circ} \mathrm{C}$ storage.

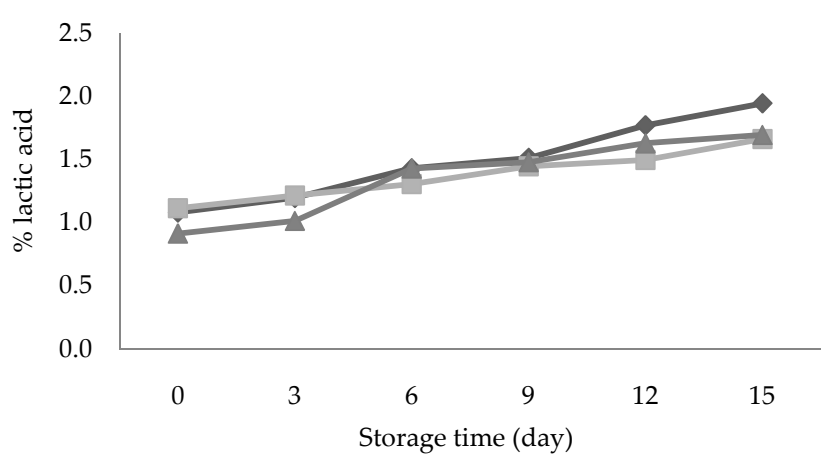

B

Figure 1. The $\mathrm{pH}$ value (A) and titratable acidity (B) of F3 yoghurt during storage at $10{ }^{\circ} \mathrm{C}$ for $15 \mathrm{~d}(-\downarrow-=$ plain, $-\mathbf{-}-=1 \%$ strawberry; - $\mathbf{\Delta -}=0.1 \%$ vanilla). F3: Formula 3 (L. bulgaricus + S. thermophilus + L. acidophilus 2B4). 


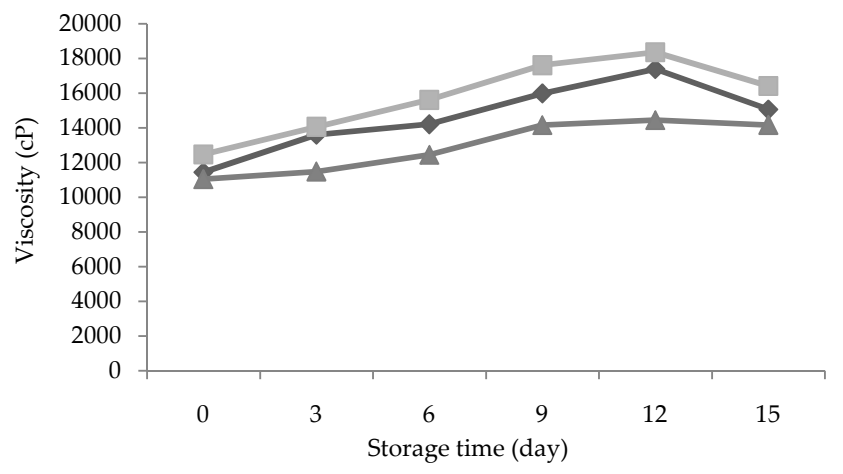

Figure 2. Viscosity of F3 yoghurt during storage at $10 \mathrm{oC}$ for 15 d (- - = plain, $-\mathbf{m -}=1 \%$ strawberry; $-\boldsymbol{\Lambda}-=0.1 \%$ vanilla $)$. F3: Formula 3 (L. bulgaricus + S. thermophilus + L. acidophilus 2B4).

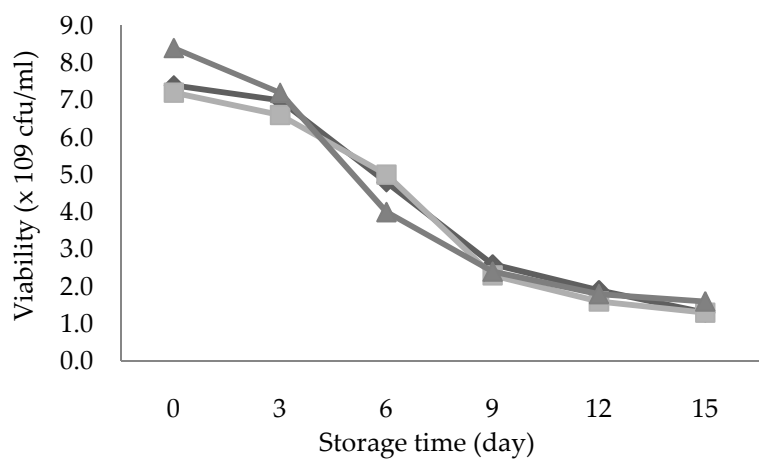

Figure 3. Lactic acid bacteria viability of F3 yoghurt during storage at $10 \mathrm{oC}$ for $15 \mathrm{~d}(--=$ plain, $-\mathbf{- -}=1 \%$ strawberry; - $\mathbf{\Delta}-=0.1 \%$ vanilla). F3: Formula 3 (L. bulgaricus $+S$. thermophilus + L. acidophilus 2B4).

\section{CONCLUSION}

F3 synbiotic yoghurt produced by using L. bulgaricus, S. thermophilus, and L. acidophilus 2B4 cultures, with the additional of $5 \%$ FOS had the highest antibacterial activity. The addition of $1.75 \%$ corn starch as a tabilizer produced a better quality characteristic of yoghurt and the addition of $1 \%$ strawberry or $0.1 \%$ vanilla as a flavor gave the highest hedonic acceptance level for the panelists. The selected F3 yoghurt had fulfilled the whole quality requirements of SNI 2981-2009. The viability of lactic acid bacteria was $10^{9} \mathrm{cfu} / \mathrm{ml}$, with good $\mathrm{pH}$ value and total of acid when the yoghurt was storage for 15 $\mathrm{d}$ in $10{ }^{\circ} \mathrm{C}$. Thus, synbiotic yoghurt could be consumed until $15 \mathrm{~d}$ of storage at $10{ }^{\circ} \mathrm{C}$.

\section{ACKNOWLEDGEMENT}

In this opportunity, we put high gratitude for Directorate of Research and Community Services,
Directorate General of Higher Education, Ministry of National Education, Republic of Indonesia, who have funded this research by Competency Grant, Contract Number: 409/SP 2 H/DP2M/VI/2010, June 11th 2010, on behalf of Made Astawan.

\section{REFERENCES}

Andersson, H., N-G Asp, A. Bruce, S. Roos, T. Wadstrom, \& A. E. Wold. 2001. Health effects of probiotics and prebiotics: A literature review on human studies. Scand. J. Nutr. 45: 58-75.

AOAC. 2005. Official Methods of Analysis in The Association of Official Agricultural Chemist. Association of Official Agricultural Chemist. Washington D.C.

Arief, I. I., B. Sri Laksmi Jenie, M. Astawan, \& A. B. Witarto. 2010. Efektivitas probiotik Lactobacillus plantarum 2C12 dan Lactobacillus acidophilus 2B4 sebagai pencegah diare pada tikus percobaan. Med. Pet. 33: 137-143. DOI: 10.5398/ medpet.2010.33.3.137

Astawan, M., T. Wresdiyati, I. I. Arief, \& E. Suhesti. 2011a. Gambaran hematologi tikus putih (Rattus norvegicus) yang diinfeksi Escherichia coli enteropatogenik dan diberikan probiotik. Med. Pet. 34: 7-13. DOI: 10.5398/medpet.2011.34.1.7

Astawan, M., T. Wresdiyati, I. I. Arief, \& D. Febiyanti. 2011 b. Potensi bakteri asam laktat probiotik indigenus sebagai antidiare dan imunomodulator. Jurnal Teknol. \& Ind. Pangan XXII:11-16.

Astawan, M., T. Wresdiyati, Suliantari, \& Y. M. S. Nababan. 2011c. Yogurt sinbiotik berbasis probiotik lokal dapat mencegah diare dan mengubah status hematologi tikus percobaan. Jurnal Veteriner (in press)

Chandan, R., C. H. White, A. Kilara, \& Y. H. Hui. 2006. Manufacturing Yogurt and Fermented Milks. Blackwell Publishing, Iowa.

Lourens-Hattingh, A. \& B. C. Viljoen. 2001. Yogurt as probiotic carrier food. Int. Dairy J. 11: 1-17.

Paseephol, T. \& F. Sherkat. 2009. Probiotic stability of yoghurts containing Jerusalem artichoke inulins during refrigerated storage. Journal of Functional Foods 1: 311-318. http:// dx.doi.org/10.1016/j.jff.2009.07.001

Quigley T. 2008. Monitoring The Growth of E. coli with Light Scattering Using The Synergy ${ }^{\mathrm{TM}} 4$ Multi-Mode Microplate Reader with Hybrid Technology ${ }^{\mathrm{TM}}$. http://www.biotek. com/resources/docs/E coli app note final format-2.pdf. [6 November 2010].

Standar Nasional Indonesia. 2009. SNI 2981-2009. Badan Standardisasi Nasional, Jakarta.

Steel, R.G.D. \& J. H. Torrie. 1995. Principles and Procedures of Statistic. A Biometrical Approach. 2 nd edition. Mc Graw Hill Book Co., New York.

Tharmaraj, N. \& N. P. Shah. 2004. Survival of Lactobacillus acidophilus, Lactobacillus paracasei subsp. paracasei, Lactobacillus rhamnosus, Bifidobacterium animalis and Propionibacterium in cheese-based dips and the suitability of dips as effective carriers of probiotic bacteria. Int. Dairy J. 14: 1055-1056.

Zubillaga, M., R. Weill, E. Postaire, C. Goldman, R. Caro, \& J. Boccio. 2001. Effects of probiotics and functional foods and their use in different diseases. Nutrition Research 21: 569-579. 